\title{
New approach to hydrogeological modelling and source data collecting in a small mountainous hard rock basin - experiences from the Sudetes Mts. (SW Poland)
}

\author{
Marek WCISŁO ${ }^{1, *}$ and Tomasz OLICHWER ${ }^{1}$
}

1 Department of General Hydrogeology, Institute of Geological Sciences, University of Wrocław, Cybulskiego 32, 50-205 Wrocław, Poland

Wcisło M. and Olichwer T. (2013) New approach to hydrogeological modelling and source data collecting in a small mountainous hard rock basin - experiences from the Sudetes Mts. (SW Poland). Geological Quarterly, 57 (2): 205-218, doi: 10.7306/gq. 1085

We demonstrate a new research methodology into flow paths and groundwater resources with in small hard rock basins, where little hydrogeological data is available, a picture may be obtained by modelling. Data has been collected in the Złoty Potok River catchment (area $4.4 \mathrm{~km}^{2}$ ), located in the eastern Sudetes Mts. (SW Poland). The study area, as for most small hard rock basins in the Sudetes Mts. is characterized by: (1) steeply sloping terrain, (2) a complex flow system connected to several media, (3) poorly constrained hydrogeological parameters. In such conditions, groundwater models are difficult to implement. To overcome these difficulties, we applied a concept of mixed flow ruled by laws of Darcy (porous media) and Hagen-Poiseuille (fractured media), and the concept of three water-bearing zones, a classic solution for scales of above several sq km, combined with a discrete fracture model. Field data applied for modelling were collected over one year, measuring all manifestations of groundwater occurrence: (1) effective infiltration (lysimeter), (2) fracture mapping, (3) stream flow and flow disappearance. As a result of modelling, specific flow domains were identified; which form a system of zones, characterized by different geometries and flow velocities. A new, previously unrecognized zone of considerable importance for water extraction, i.e. fractures in the river valley axis, reaching a deep part of the orogen (up to $300 \mathrm{~m} \mathrm{b.g.l.)}$ ) was defined. The relationships investigated allowed prepation of a prognosis for deep groundwater intake locations in poorly described mountainous areas. The success of the solutions obtained in this typical mountainous river basin suggests that this method may be come efficiently and widely used in other hard rock areas. The research undertaken offers an innovative, efficient approach to groundwater resource assessment in hard rock.

Key words: groundwater resources, hard rock, hydrogeological modelling, Sudetes Mts.

\section{INTRODUCTION}

Hard rock outcrops cover about $20 \%$ of the land surface (Faillace, 2003). The main area of hard rock outcrop in Poland is the Sudetes Mts. (SW Poland; Fig. 1). The Sudetes crystalline area has been classified by many authors (e.g., Kleczkowski, 1979; Paczyński, 1995) as a region with a low groundwater capacity or even as being waterless with a poor supply. Previous hydrogeological studies have indicated that crystalline massifs are characterized by profuse groundwater recharge and a slow depletion of water resources (Kryza and Kryza, 1986; Staśko, 1996; Tarka, 1997; Olichwer, 2003, 2007a, b). In the central and eastern parts of the Sudetes Mts. groundwater runoff is significant and varies from 6.8 to $8.81 \mathrm{dm}^{3} / \mathrm{s} \cdot \mathrm{km}^{2}$ on hard bedrock (Olichwer, 2007b). Similar values were also noted for other river basins (crystalline rock areas), where the groundwater runoff oscillates between 4.07 and $15.39 \mathrm{dm}^{3} / \mathrm{s} \cdot \mathrm{km}^{2}$, averaging 6.99 $\mathrm{dm}^{3} / \mathrm{s} \cdot \mathrm{km}^{2}$ (Olichwer, 2007a).

\footnotetext{
* Corresponding author: marek.wcislo@ing.uni.wroc.pl
}

Received: January 27, 2011; accepted: November 13, 2012; first published online: April 18, 2013
One crucial problem needing investigation is the water resources of hard rock areas (Davis, 1964; Wright, 1992; Banks et al., 1994; Bocanegra and Cardoso, 2003). With relatively high groundwater runoff and considerable groundwater recharge, the Sudetes region struggles with water shortages. One example is the Złoty Stok area (Figs. 1 and 2) where water consumption is based upon drainage intake. Each year water flow disappears in some parts of the streams for over a month and a significant fall in water production at the water intake can be noticed. A divergence between the recognized average groundwater discharge and the water resource available for the population has been noted. For that reason, the determination of a means to achieve stable groundwater resources is essential.

This paper describes a new research methodology concerning flow paths and groundwater resources within small hard rock basins. Given a scarcity of hydrogeological data, we have applied a unique solution: a combination of the conceptual models of Equivalent Porous Medium (EPM) and Discrete Fracture Network (DFN) in conditions of complex mountainous catchment.

We suggest that this solution may provide a basis for applying this methodology in many similar hard rock basements, where hydrogeological parameters are usually poorly constrained. 


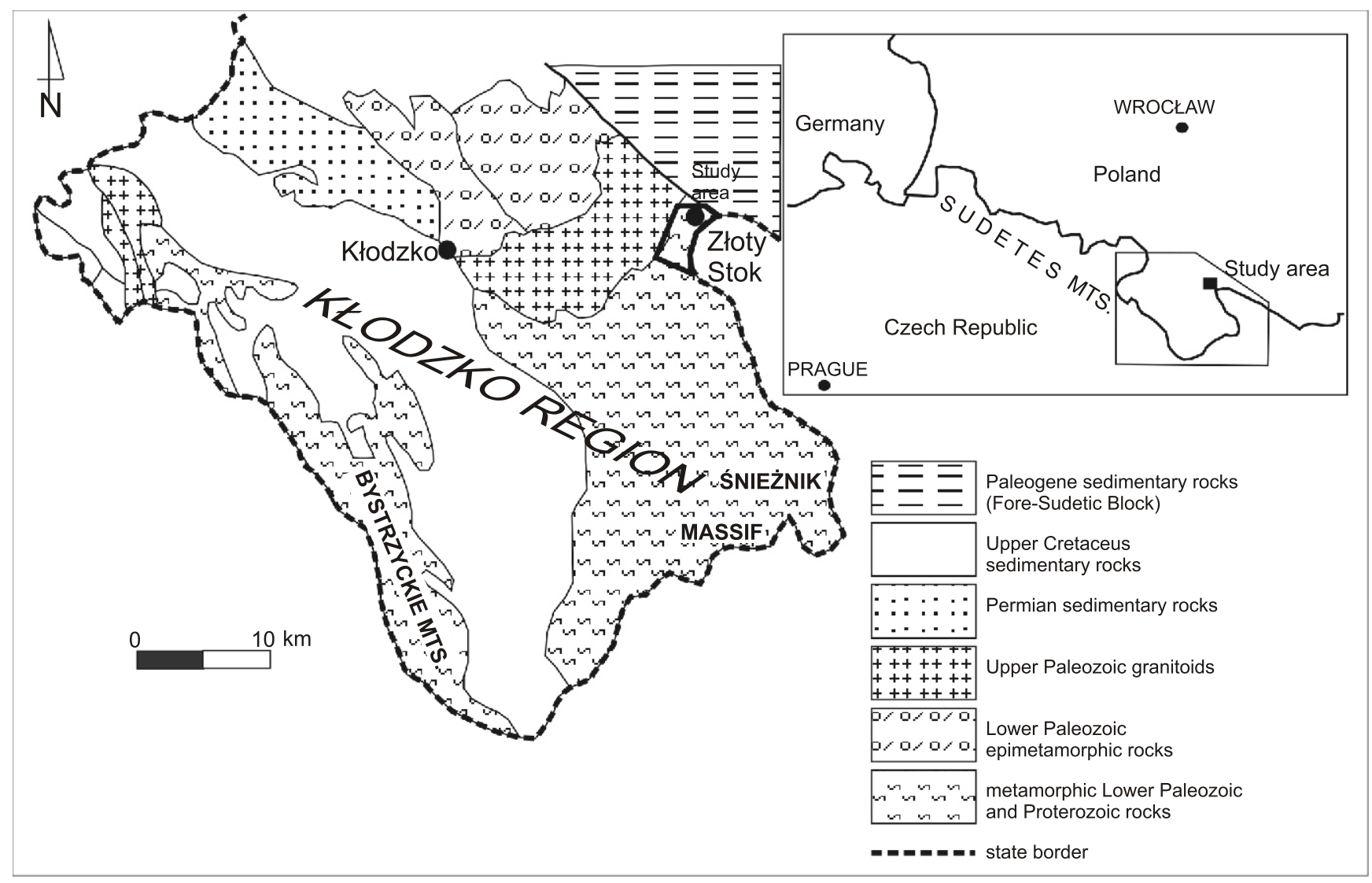

Fig. 1. Geological map of the Kłodzko region (according to Sawicki, 1967)

\section{STUDY AREA}

The Złoty Potok River catchment $\left(4.4 \mathrm{~km}^{2}\right)$ is situated in the eastern Sudetes Mts. (Figs. 1 and 2). In the research area Paleozoic hard rocks (gneisses, mica-schists, marbles, amphibolites, lepthynites, granites) occur in a dome-like structure. Most of the study area comprises outcrops of metamorphic schists and gneisses. Leptynites, amphibolites and other crystalline rocks occur in the form of lenses and interrelations within the schists and gneisses. Their contact is usually tectonic, less commonly gradual. In the research area as well as in the entire Sudetes Mts., dominate NNE-SSW structural directions. Lithological boundaries are typically tectonic (Wojciechowska, 1995). The Złoty Potok River (the main river in the study area) is founded on a fault, the Marginal Sudetic Fault separating the Sudetes Mts. from the Fore-Sudetic Block.

Geologically the research area belongs to the metamorphic unit of the Złote Mts., one of the many elevated areas of the Sudetes Mts., built of igneous and metamorphic rocks. The geological conditions of the Złoty Potok River Basin are similar to raised areas of the Sudetes Mts., such as, for example, the Lądek-Śnieżnik Massif, the metamorphic unit of the Orlica-Bystrzyckie Mts. or the Karkonosze Massif. All of these units have been subjected to weathering processes, giving rise to similar distributions of fissures and weathering covers. Weathering phenomena have affected both metamophic and igneous rocks.

In the area of research the crystalline rocks are overlain by a weathering cover and Quaternary fluvial deposits (sands, clays). The thickness of this cover varies from 0 to $5 \mathrm{~m}$.
The crystalline rocks have to be considered as an important environment of groundwater recharge, because they form up to $50 \%$ of the Sudetes Mts. area.

Hydrogeological parameters of the Złoty Potok River Basin have not been the subject of previous studies. In order to complete the data base adequately to the needs of the numerical model, we have used the results of their own measurements, though also geological analogues for other elevated areas of the Sudetes Mts. Data from other regions considered subsequently was calibrated by the numerical model.

Groundwater in hard rocks of all elevated areas of the Sudetes Mts. as well as in the study area occurs in three environments (Kowalski, 1992; Staśko and Tarka, 2002) that maintain some hydraulic contact. A similar situation has also been widely recognized in another regions of the world (Pickens et al., 1987; Lachassagne et al., 2001; Probst, 2003; Dewandel et al., 2006; Gentry and Burbey, 2007). These zones are:

Zone 1. Weathered and Decayed Rock (WDR) is characterized by clayey sediments with high specific yield and low hydraulic conductivity. This layer is highly discontinuous, but provides recharge for underlying areas. Weathered covers are presented by rubble, soliflucted clay (slope clay) and river-bed sediments. The thickness of the zone is dependent on the geomorphological position and ranges from $0 \mathrm{~m}$ in the summit areas to $5 \mathrm{~m}$ in river valleys. Recharge of WDR takes place directly by precipitation (Staśko and Tarka, 2002).

Zone 2. The Weathered-Fissured Zone (WFZ) in intrusive igneous and metamorphic rocks is characterized by high flow velocities and low specific yield. The WFZ comprises rock divided by weathering fissures. The number of which increases towards the surface (Tarka, 1997). This zone in the Sudetes 


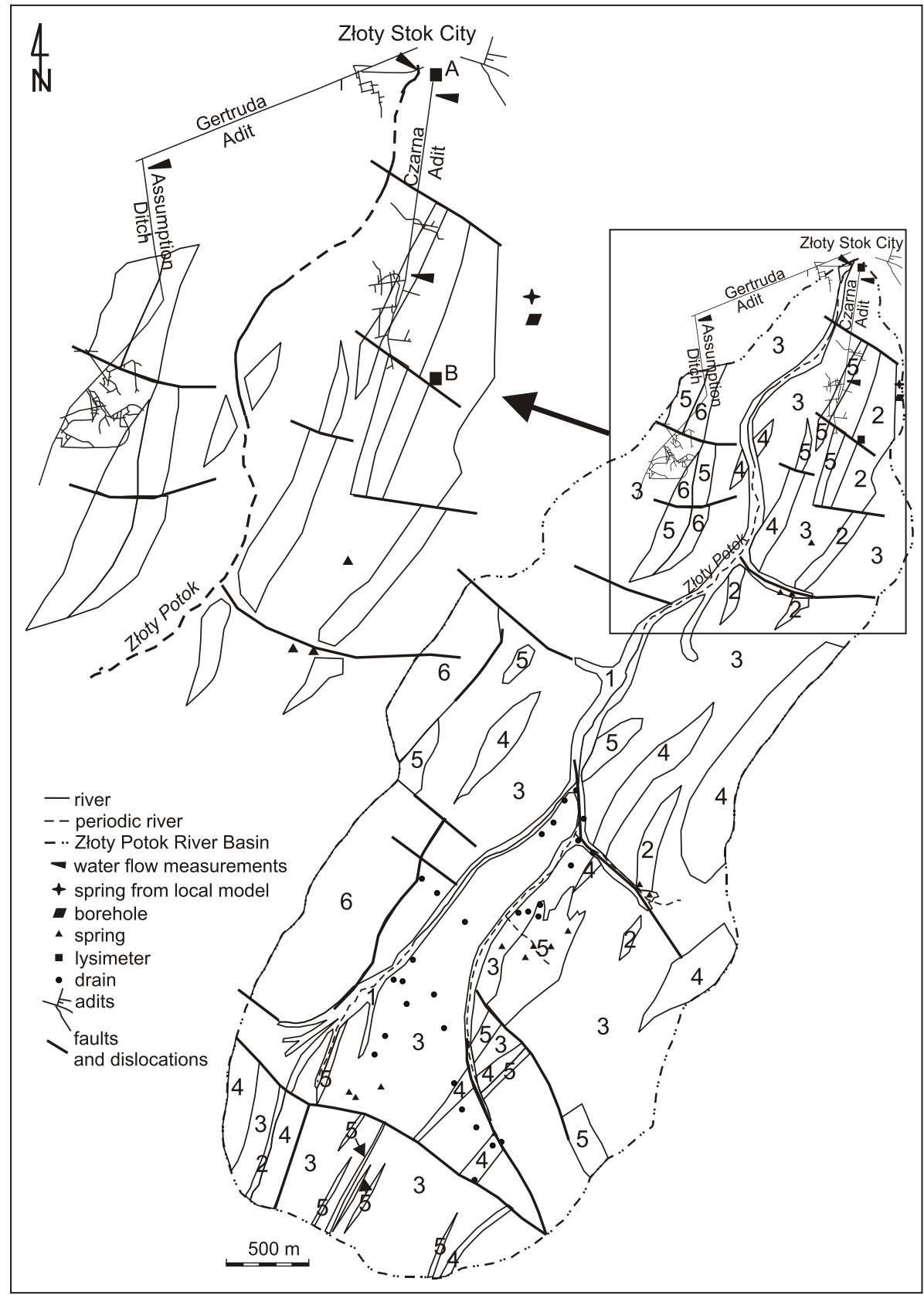

Fig. 2. Geological map of the Złoty Potok River Basin

1 - fluvial deposits (Holocene), 2 - amphibolites (Lower Paleozoic), 3 - metamorphic schists (Lower Paleozoic), 4 - leptynites (Lower Paleozoic), 5 - metamorphic marbles (Lower Paleozoic), 6 - gneisses (Lower Paleozoic)

Mts. reaches a thickness up to $60 \mathrm{~m}$ (Staśko and Tarka, 2002; Staśko, 2010). The thickness in the study area is in the range of $20 \mathrm{~m}$. Recharge of the WFZ takes place by seepage from higher zone (WDR) or directly from rock exposures.

Zone 3. Fractured Bedrock (FB), which controls stable river outflow in regional system, is characterized by low hydraulic conductivity and specific yield, though locally higher (Staśko, 2010). FB is built of solid rock beyond the reach of weathering. The thickness is 500-600 m, and in the case of thermal waters even more (Zuber et al., 1995). Recharge of FB takes place mainly by seepage from the higher zone (WFZ).

Staśko (1996) collected data from 44 hydrogeological boreholes and analysed water bearing zone occurrences in the
Sudetes Mts. The thickness of all the zones above impermeable crystalline rocks is approximately $100 \mathrm{~m}$, with a maximum of $586 \mathrm{~m}$.

The hydraulic conductivity $(k)$ was studied by Staśko and Tarka (2002) in the Śnieżnik Massif. They analysed the isotopic composition of springs and old mine waters and estimated the time of flow through the rock environment. In addition, they used laboratory methods to evaluate the filtration parameters of weathered covers and fractured bedrock and took data from previous literature by this. They obtained average values for the weathered cover zone of $0.1 \mathrm{~m} / \mathrm{d}$, and for the fractured massif of approximately $1 \mathrm{~m} / \mathrm{d}$. In zones 2 and 3 , only $0.1 \%$ of the fractures can accommodate groundwater (Berkowitz, 2002). In turn 
using spring regression analysis and borehole observation, supported by laboratory studies (centrifuge method), the specific yield $(\mu)$ has been estimated by authors as 0.23 (weathered zone 1) and 0.04 (fractured massif of zone 2). The deep fault zone 3 is characterized by low parameters for both specific yields $(\mu=0.0001-0.001)$ and filtration $(k=0.001-0.1 \mathrm{~m} / \mathrm{d})$ (Zuber et al., 1995; Staśko and Tarka, 2002). The hydraulic conductivity in zone 3 was determined at regional scale from tracer age and matrix porosity results using empirical formulas.

On the basis of studies of water balance and tectonic analysis, Kowalski (1992) concluded that groundwater and surface-water divides are coincident. The results (Kowalski, 1992) indicate that the lateral inflows are negligible in case of the river basin with watersheds clearly marked in the morphology.

Drainage in all the zones takes place as springs and river bed inflow (Olichwer, 2007a). Water in the weathered mantles determines spring discharge for most of the year quantitatively and temporally. This is supported by spring recession tests in the Śnieżnik Massif (Staśko, 1996), Bystrzyckie Mts. (Olichwer, 2007a) and Karkonosze Mts. (Kryza and Kryza, 1988). Studies of natural outflows in the Sudetes Mts. (Staśko, 1996; Tarka, 1997; Olichwer, 2007a) indicate that the springs supplied from the zone of weathered mantle are characterized by low and variable discharge.

In the northern part of the research area (Fig. 2), a disused closed mine of gold and arsenic ore is situated. Currently two tunnels are available (Gertruda and Czarna), which are located in metamorphic rocks. We measured the mean flow in the Czarna Adit from December 2005 to December 2006 as $13.14 \mathrm{dm}^{3} / \mathrm{s}$. Water comes from infiltration (inflow) of surface water from outside the river catchment area (Ciężkowski and Błażej, 1995). In the Gertruda Adit observations show that water flows through the tunnel from the mining area which is located outside the Złoty Potok River catchment. We made observations of outflows from the walls and these indicate that the volume of water from the Złoty Potok River Basin is minimal. A second branch discharges water from the study area. Average outflow from the tunnel that originates from the Złoty Potok River catchment is $10.15 \mathrm{dm}^{3} / \mathrm{s}\left(2.4 \mathrm{dm}^{3} / \mathrm{s} \cdot \mathrm{km}^{2}\right)$.

The hydrogeological medium of study area is characterized by instability of groundwater resources occurring in the weathered mantle of crystalline rocks. It is also not easy to find water-bearing fractured zones in the rock massif and in fault zones, linked with the deeper circulation of groundwater, using low-cost techniques. This situation is typical for many areas of crystalline rocks in the world, for example southern France (Lachassagne et al., 2001), Ivory Coast (Lenck, 1977) and southern India (Balamurugan et al., 2010).

\section{FIELD DATA}

Field data gathered from the Złoty Potok River catchment comprised: measurements of flow in rivers, springs and adits, lisymeter measurements and their analyses combined with detailed mapping of fracture distribution and groundwater inflows these served to define the conceptual model and its numerical realisation.

\section{RECHARGE AND GROUNDWATER RUNOFF}

Recharge of the Złoty Potok River catchment was assessed on the basis of data mainly from precipitation gauging stations. Two lysimeters A (upper) and B (lower) were placed in different morphological positions (377 and $500 \mathrm{~m}$ a.s.l.) in the study area (Fig. 2) of a depth of $1.1 \mathrm{~m}$. Each of them was gauged separately by monthly measurements of infiltration water volume. Lysimeters $A$ and $B$ registered the infiltrations: $272 \mathrm{~mm}$ $\left(8.64 \mathrm{dm}^{3} / \mathrm{s} \cdot \mathrm{km}^{2}\right)$ and $218 \mathrm{~mm}\left(6.9 \mathrm{dm}^{3} / \mathrm{s} \cdot \mathrm{km}^{2}\right)$, respectively, for a one year-period (2006). In addition, the infiltration was compared to groundwater runoff calculated from hydrograph-separation methods for the period from 01.11.2005 to 30.10.2006 (Fig. 3). On the basis of daily flow in the gauging station located in the research area, the sum of groundwater runoff separated from the hydrograph $\left(5.36 \mathrm{dm}^{3} / \mathrm{s} \cdot \mathrm{km}^{2}\right)$ and discharge analysis from the tunnel $\left(2.4 \mathrm{dm}^{3} / \mathrm{s} \cdot \mathrm{km}^{2}\right)$ was then taken into consideration $\left(248 \mathrm{~mm}-7.86 \mathrm{dm}^{3} / \mathrm{s} \cdot \mathrm{km}^{2}\right)$. This fits into limits determined by both lysimeters and represents the mean value for the entire research area. The agreement obtained indicates that retention influence on a one-year water balance is negligible.

The chosen test period is representative of average multiyear conditions. The sum of percipitation in Złoty Stok (the main town in the study area) for the hydrological year 2006 amounted to $894 \mathrm{~mm}$, while for the multiyear 1970-1981 it was $882 \mathrm{~mm}$ (data from Institute of Meteorology and Water Management - IMWM).

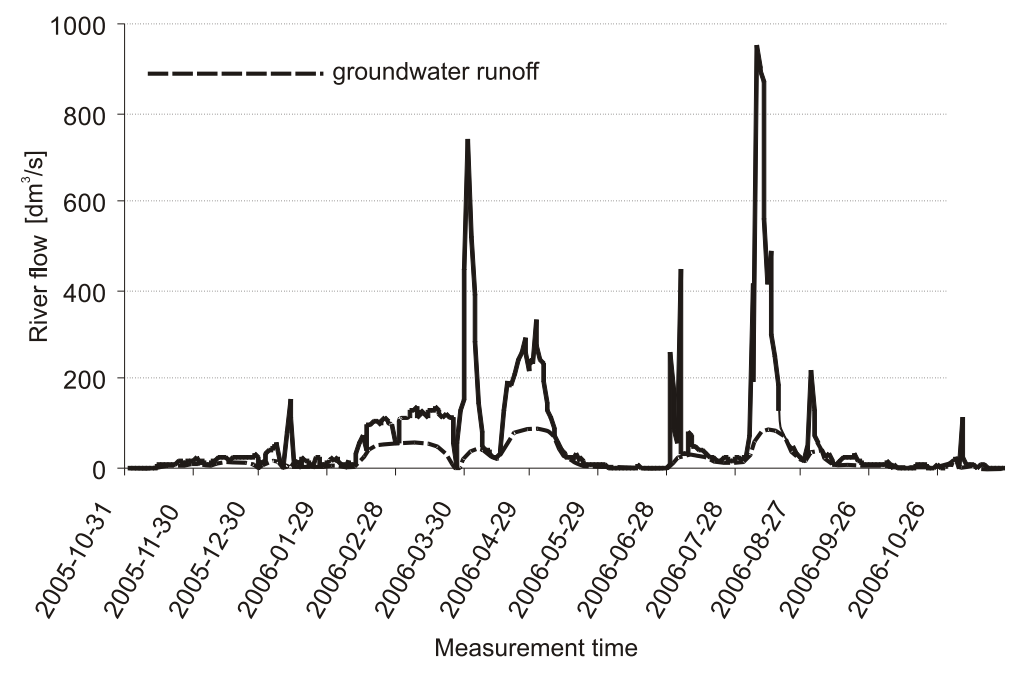

Fig. 3. Hydrograph of the Złoty Potok River 
Hydrogeological parameters of the spring basin model

\begin{tabular}{|c|c|c|}
\hline Model parameter & Value & $\begin{array}{c}\text { Reliability } \\
\text { level }\end{array}$ \\
\hline \multicolumn{3}{|c|}{ Input parameters (hydrogeological data) } \\
\hline Transmissivity of preferential flow paths & $3.6 \cdot 10^{-4}-3.6 \cdot 10^{-3} \mathrm{~m}^{2} / \mathrm{s}$ & high \\
\hline Conductivity of matrix & $4 \cdot 10^{-8} \mathrm{~m} / \mathrm{s}$ & low \\
\hline Spacing of preferential flow paths & $80 \mathrm{~m}$ & high \\
\hline Thickness of first/second layer & $5 \mathrm{~m} / 20 \mathrm{~m}$ & high \\
\hline Orientation & according to rose of fractures & high \\
\hline Conductivity of WDR & $10^{-6} \mathrm{~m} / \mathrm{s}$ & low \\
\hline \multicolumn{3}{|c|}{ Parameters after calibration (model output data) } \\
\hline Spring discharge discrepancy & $1.4 \mathrm{dm}^{3} / \mathrm{s}$ & \\
\hline Ratio initial to final discharge & $7 \%$ & \\
\hline Transmissivity of preferential flow paths & $4 \cdot 10^{-3} \mathrm{~m}^{2} / \mathrm{s}$ & \\
\hline Conductivity of matrix & $1.2 \cdot 10^{-8} \mathrm{~m} / \mathrm{s}$ & \\
\hline
\end{tabular}

\section{HYDROGEOLOGICAL PARAMETERS}

The average thickness of the two zones (WDR, WFZ) was assessed on the basis of our observations of water-bearing fissures in mine adits. The weathered cover was observed to be $5 \mathrm{~m}$ thick and the fissured rock $20 \mathrm{~m}$ thick on average (Table 1 ). The bottom of third zone was assigned according to the assumption of necessity to simulate the system to the depth of possible exploitation of freshwater $(300 \mathrm{~m}$ b.g.I.).

Only a few fractures (about $0.1 \%$ ) were recognized to be water-bearing. All of them were vertically- or subvertically-oriented. The horizontal structures are likely filled with weathered material and remain less permeable. The rock matrix, which surrounds preferential flow paths contains some volume of water, but it was impossible to measure any flow in this zone. These observations suggest a model of double permeability can be applied in the case of the Złoty Potok River Basin, where major water-bearing fractures are surrounded by a low permeability matrix which provides limited hydraulic connection. The system in this conception is composed of DFN and EPM.

There was observed local hydraulic connection between river and adits resulting in small inflows through single fractures (Fig. 4). Permeability was calculated according to following formula:

$$
T=\frac{Q}{(\Delta h / s) \times I}
$$

where: $s$ - distance between river and adit [m]; $\Delta h$ - difference of $\mathrm{z}$-coordinate between water level in river and point of discharge [m]; $Q$ - discharge from the fracture $\left[\mathrm{m}^{3} / \mathrm{s}\right] ; I$ - fracture length; $T$ transmissivity $\left[\mathrm{m}^{2} / \mathrm{s}\right]$.

We collected values of $s, \Delta h$ and I during detailed hydrogeological mapping of the mine tunnels of the Czarna Adit (8 m b.g.l.) and the Złoty Potok River valley. Discharge $(Q)$ was measured directly in the wall of the Czarna Adit. An output of between $3.6 \cdot 10^{-4}-3.6 \cdot 10^{-3} \mathrm{~m}^{2} / \mathrm{s}$ was obtained on the basis of five measurements.

The storage coefficient was derived from discharge recession and measurements water table of the during 2006 (Fig. 5) according to the formula:

$$
S=\frac{d W}{d H}
$$

where: $S$ - storage coefficient; $d W$ - change in groundwater storage [m] (Wright, 1980); $d H$ - water table lowering in borehole [m].

Mailet's formula was applied to calculate $d W$ :

$$
\begin{gathered}
d W=W-W \\
W=\frac{Q_{0}}{\alpha} \\
W=\frac{Q_{0}^{\prime}}{\alpha} \\
\alpha=\frac{\lg \left(Q-Q_{0}\right)}{0.4343 t}
\end{gathered}
$$

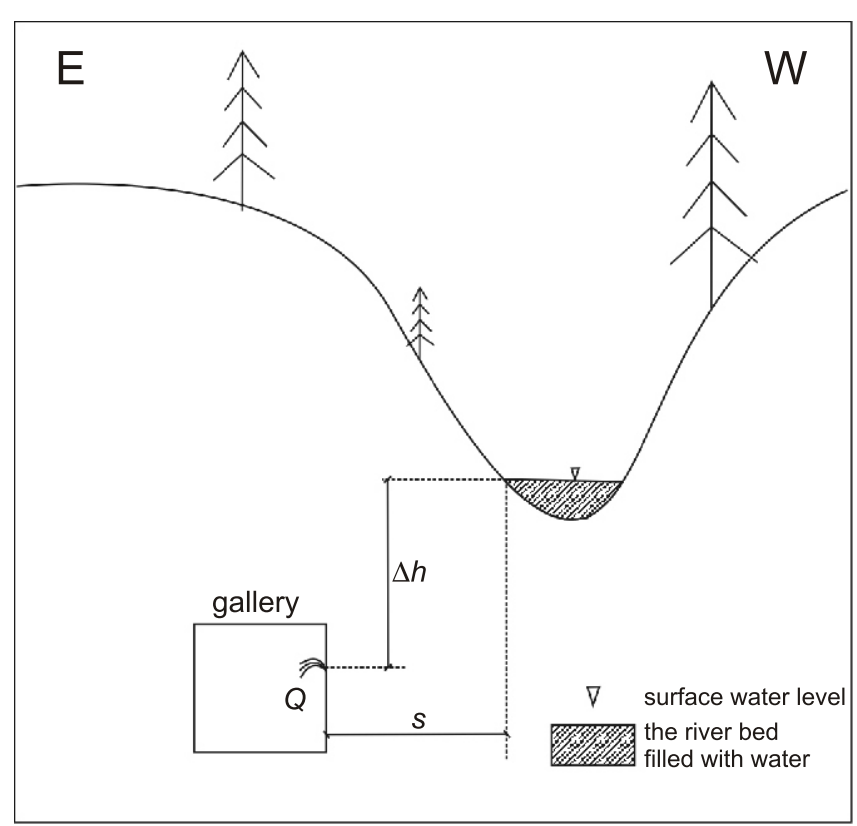

Fig. 4. Schematic diagram showing the method of transmissivity calculation

Explanations as in Equations 1 


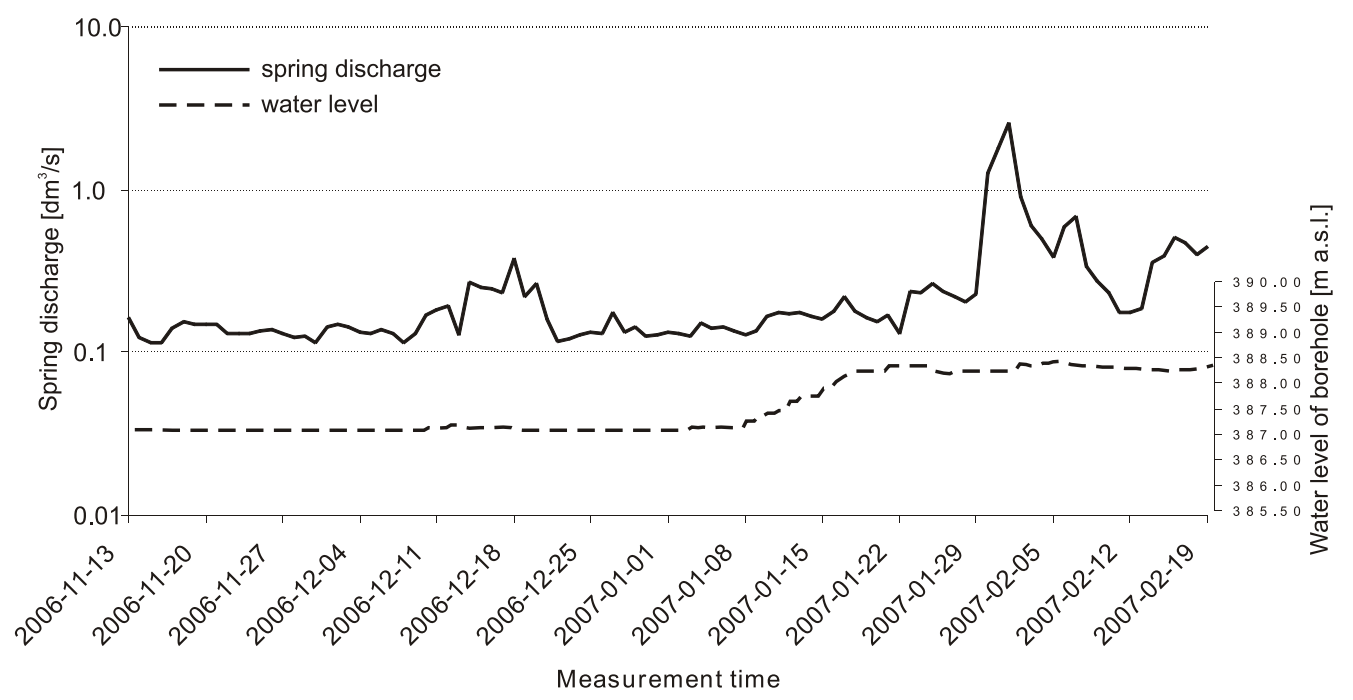

Fig. 5. Spring discharge against the background of water table changeability

where: $Q_{0}$ - spring discharge at the beginning of regression $\left[\mathrm{m}^{3} / \mathrm{s}\right]$ $Q_{0}^{\prime}$-spring discharge at the end of regression $\left[\mathrm{m}^{3} / \mathrm{s}\right] ; \alpha$ - regression coefficient; $t$ - time of regression [day].

Values of storage coefficient ware calculated on the basis of the steepest regression curve (non-recharge) in the time period analysed. The values were obtained: 0.039 for fractured rock (WFZ) and 0.23 for weathered cover (WDR).

The hydrogeological parameters of zone $3(\mathrm{FB})$ are considerably more difficult to assess. The inaccessibility of fissures for observation excludes hydraulic aperture estimation. For this reason, the lower limit of the aperture observed in the mine workings $\left(8.7 \cdot 10^{-4} \mathrm{~m}\right)$ was used and this initial value was investigated in the calibration process. The measure of permeability of the rock matrix was set at the same value as in zone 2 . The structures permitting the principal flow were also identified within a Monte Carlo simulation (Table 2). The divergence seen may be attributed to the small number of fracture zones (105).

There was no information on permeability of the weathered cover (WDR) - this factor was obtained as a solution of inverse modelling. As the input data, the value of $10^{-6} \mathrm{~m} / \mathrm{s}$ proposed by Staśko and Tarka (2002) was initially applied to the local model that we created.

\section{METHODS}

To solve the problem of water resources availability in a small, hard rock basin such as example the Złoty Potok River Basin (Figs. 1 and 2), by modeling, a conceptual model was created based on the concept of mixed flow ruled by: the Darcy (porous media) and Hagen-Poiseuille (fractured media) laws.

Early conceptual models (Snow, 1969) for groundwater flow in crystalline rocks were based on the idea of EPM (Equivalent Porous Medium). Long at al. (1985) suggested and Cacas et al. (1990) developed the Discrete Fracture Network (DFN) model and recognized that fractures form disc-shaped structures of random size and orthogonal or random orientation. The DFN model is usually limited to small-scale investigations ( $\mathrm{cm}$ to tens

Input parameters to the Monte Carlo simulation method (fractured massif zone 2, fault zone 3)

\begin{tabular}{|c|c|c|c|c|c|c|c|c|}
\hline \multirow{3}{*}{ The range of coordinates of fracture ends } & \multicolumn{4}{|c|}{ Fractured massif - zone 2} & \multicolumn{4}{|c|}{ Fault - zone 3} \\
\hline & $x_{\min }$ & $y_{\min }$ & $\mathrm{x}_{\max }$ & $\mathrm{y}_{\max }$ & $x_{\min }$ & $y_{\min }$ & $x_{\max }$ & $y_{\max }$ \\
\hline & 8387 & 18530 & 10915 & 22260 & 8387 & 18530 & 10915 & 22260 \\
\hline Length of fracture $(\min / \mathrm{max})[\mathrm{m}]$ & \multicolumn{4}{|c|}{ 2/155 } & \multicolumn{4}{|c|}{ 30/155 } \\
\hline Number of fractures per surface unit $\left[1 / \mathrm{m}^{2}\right]$ & \multicolumn{4}{|c|}{0.000156} & \multicolumn{4}{|c|}{0.0000111} \\
\hline Simulation area $\left[\mathrm{m}^{2}\right]$ & \multicolumn{4}{|c|}{9426672} & \multicolumn{4}{|c|}{9426672} \\
\hline Number of fractures & \multicolumn{4}{|c|}{1473} & \multicolumn{4}{|c|}{105} \\
\hline Azimuth of fractures $\left[^{\circ}\right]$ & & & & & \multicolumn{4}{|c|}{290} \\
\hline Azimuth of I fractures complex $\left[^{\circ}\right]$ & \multicolumn{4}{|c|}{310} & & & & \\
\hline Azimuth of II fractures complex $\left[{ }^{\circ}\right]$ & \multicolumn{4}{|c|}{20} & & & & \\
\hline Appearance probability of I fractures complex & \multicolumn{4}{|c|}{0.69} & & & & \\
\hline Appearance probability of II fractures complex & \multicolumn{4}{|c|}{0.31} & & & & \\
\hline Location & \multicolumn{8}{|c|}{ according to observed water-bearing fractures by authors (Fig. 7) } \\
\hline
\end{tabular}


of meter) and the EPM model serves to describe larger areas (hundreds of metres to of hundreds kilometres).

Most authors agree that treating crystalline rocks with a weathering cover as two, interconnected systems is essential for a workable conceptual model in most cases (Detay et al., 1989; Kowalski 1992; Taylor and Howard, 2000; Staśko and Tarka, 2002; Ruch and Kupfersberger, 2003). Lachassagne et al. (2001) proposed considering three compartments of a fractured aquifer: the alterites (Weathered and Decayed Rock, WDR), the underlying Weathered-Fissured Zone (WFZ) and Fractured Bedrock (FB).

Lachassagne et al. (2001) reported that essential role in groundwater storage is played alterites (WDR) with a Weathered-Fissured Zone (weighting coefficient 0.4 ). Deep fracturing of third zone is less important (respectively - 0.1). Weathered rock is responsible for retention (significant water-retention capacity and low permeability) because of its clay-sandy composition and recharge of underlying zones (Oloffson, 1994). The infiltration of precipitation functions partially under unsaturated conditions. Effective porosity evaluated on the basis of laboratory study and supported by the Proton Magnetic Resonance Method on areas of weathered covers of metamorphic rocks (north France) equals several percent (Wyns et al., 2004). Staśko and Tarka (2002) on the basis of a recharge and drainage model in mountainous areas of the Sudetes Mts. such as the Śnieżnik Massif suggested an average value of $12 \%$. Effective porosity determined in the laboratory in the range from 7 to $14 \%$ for soliflucted clay lying on schists and gneisses of the Kamienica River Basin (Śnieżnik Massif) was suggested by Tarka (1997).

The underlying zone of WDR has a variable thickness, usually from 2 to 60 m (Staśko and Tarka, 2002; Dewandel et al., 2006). The permeability of this layer is controlled by dense fracturing that decreases with depth (Houston and Lewis, 1988; Marechal et al., 2004). In some cases (Howard et al., 1992) there is no significant correlation between depth of pucker test and permeability. This phenomenon is explained by the complex nature of recharge from the upper zone of weathered rock.

The permeability of the deepest zone (FB) is several magnitudes lower than that of the fissured zone (Pickens et al., 1987; Walker et al., 2001; Kuusela-Lahtinen et al., 2003). Based on environmental isotope and noble gas data in the Lądek Zdrój area (Zuber et al., 1995) the average hydraulic conductivity of all zones was estimated at $0.8 \cdot 10^{-8}-1.6 \cdot 10^{-8} \mathrm{~m} / \mathrm{s}$ and porosity on the basis of evaluated total volume of water in the system at $0.5-1.4 \%$. Significant groundwater movement can be observed only in an isolated tectonic zone. For purpose of water resources assessment FB is assumed to be impermeable (Dewandel et al., 2006). Another conclusion was drawn by Gentry and Burbey (2007) on the basis of observation of spring hydrographs. In low season, base flow of springs is provided by groundwater from a deep fault zone.

Kowalski (1992) described a typical profile of WDR in shafts, analysed pumping tests and observed the drilling of 25 boreholes. He proposed a model for the Sudetes Mts., with typical geological settings and hydrogeological conditions. Kowalski (1992) defined three zones (WDR, WFZ, FB).

This literature suggests that the conceptual model of a hydrogeological system is generally similar for all hard rock regions and thus it can be applied also to the Złoty Potok River catchment (Figs. 1 and 2).

\section{MODELLING STUDIES}

Research was divided into two stages. First, the local model was created, and then these findings were used to adapt the investigations to the whole river basin.
The first stage involved an estimation of the parameters of the superficial areas of the massif. That process used the equivalent model of the porous medium and was carried out using the Visual MODFLOW program (McDonald and Harbaugh, 1988).

The next stage exploited the FEFLOW code (Diersch, 2005), enabling a more stochastic approach to be made to the conceptual model, that is comparable to the individual fracture approach. The FEFLOW code program (WASY Gmbh, Berlin, Germany) solves the partial differential equation of filtration in a discrete area of finite elements in 3D space by taking the shape of a cut pyramid on a polygon basis (triangle, square, hexahedron and nonagon). In general, the FEFLOW code is based on solving the Darcy equation for filtration.

\section{LOCAL MODEL - FIRST STAGE}

At the first stage of investigation a small-scale, transient flow conditions, we constructed a spring catchment model for an area of $0.25 \mathrm{~km}^{2}$ for inverse solution for parameters of WDR (Fig. 6). The method of solving an inverse task on a small-scale model to recharge in data a larger one was suggested by Manga (1999). In our case this solution is fully justified because of the good stability of the small transient model in conditions of steep hydraulic gradients. An attempt to adopt it to the model of the entire Złoty Potok River Basin failed.

A basin with a single spring was investigated, mainly during the period of the outflow recession. The spring was selected as representative for the entire water basin. The flow measurement shows the close relationship between the spring and the Złoty Potok River (Pearson's coefficient equals 0.84). This suggests analogy in recession of both flow and hydrogeological conditions. It was additionally confirmed by six shallow boreholes that suggested a WDR thickness of $5 \mathrm{~m}$.

The morphological position of the model was chosen to represent superficial drainage of the massif (WDR and WFZ). The watershed of the spring is not easy to define because of a low connection with morphology, but it can be assessed by means of the model calibration. The area resulting from mean (09.2005-09.2006) spring discharge $\left(0.21 \mathrm{dm}^{3} / \mathrm{s}\right)$ and effective infiltration of $242 \mathrm{~mm}$ (lysimetric measurements) was estimated at $0.03 \mathrm{~km}^{2}$. The assumed area of the model $\left(0.25 \mathrm{~km}^{2}\right)$ allowed the natural formation of watersheds of much smaller catchments.

Because of poor knowledge of the groundwater level, it was decided to perform the two-layer, transient flow model in five steps of one month each. The parameters and structure of the local model were based upon our observations in the mine workings (Table 1). The upper limit of the system is the ground surface because of the unconfined character of the groundwater table. The bottom of the model was determined at a depth of $20 \mathrm{~m}$ b.g.l. from the findings on the seepages inside the mine tunnel. Recharge was estimated by authors from lysimeter $A$, located in a similar morphological setting to the spring investigated. For the first time step (Table 3), the simulation was under conditions of steady state flow (a period of 3650 days was taken as the steady-state condition) and mean annual recharge (242 mm). Mean annual recharge and corresponding spring discharge for steady-state conditions were obtained during one year of observation (09.2005-09.2006). Next four, one-month periods (Table 3 ) were characterized by very low infiltration, less then $4.2 \mathrm{~mm}$ per month.

In the progress of calibration, the accordance criteria were tested for the spring discharge observed and calculated for all time periods. The examples of the model reaction for parameter changing are listed in Table 4. The calibration of the model created a database for the whole of the Złoty Potok River Basin. After numerous failed tests of calibration, to meet the convergence and accordance criteria for flow, it was necessary to introduce 


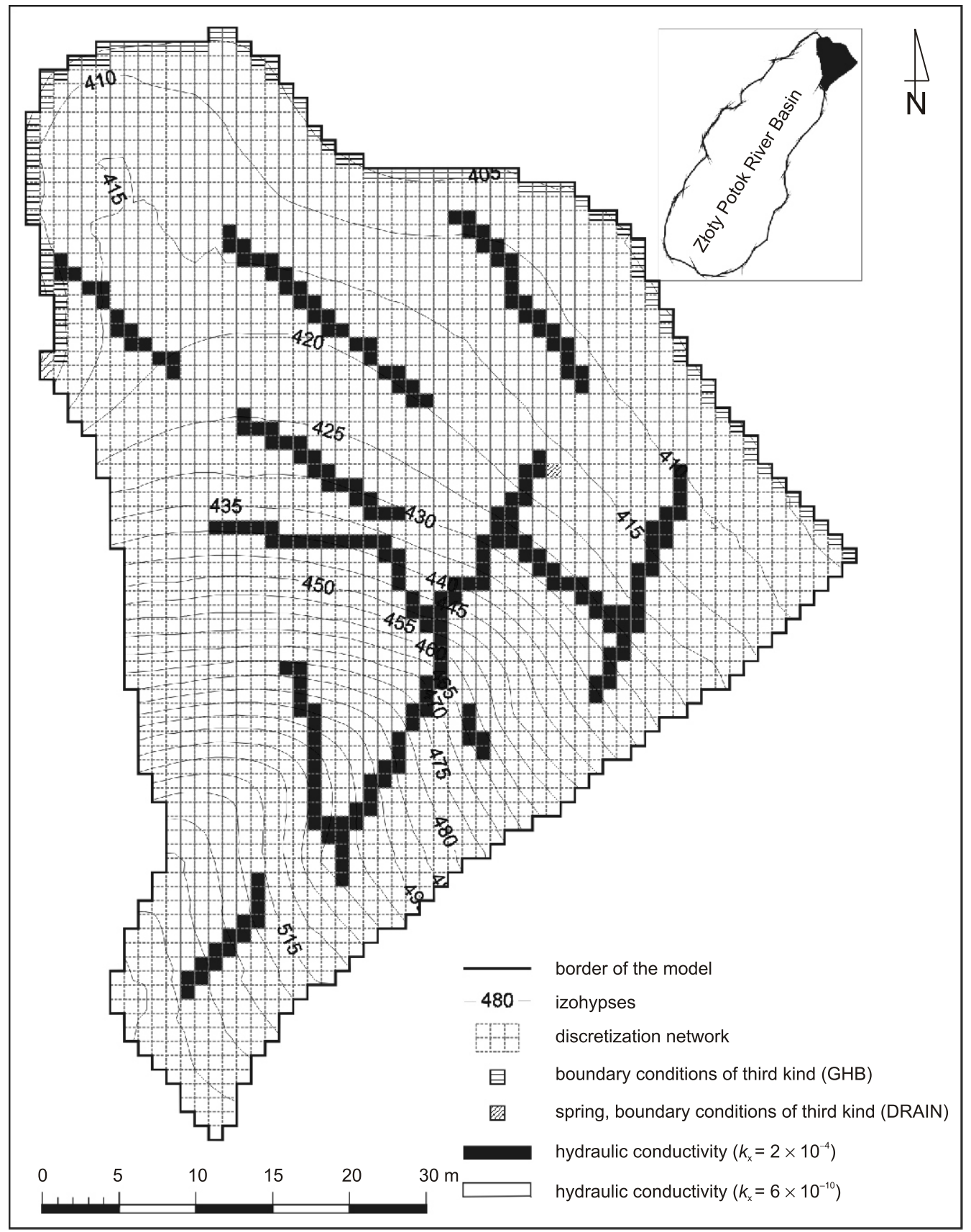

Fig. 6. The structure of the local spring basin model

Table 3

Time steps for transient simulation

\begin{tabular}{|l|c|c|c|c|}
\hline Time step & Date & Day of simulation & $\begin{array}{c}\text { Spring discharge } \\
{\left[\mathrm{dm}^{3} / \mathrm{s}\right]}\end{array}$ & $\begin{array}{c}\text { Infiltration (recharge) } \\
{[\mathrm{mm}]}\end{array}$ \\
\hline 1 & 04.09 .2006 & 3650 & 0.21 & 242 \\
\hline 2 & 04.10 .2006 & 3680 & 0.04 & 2.5 \\
\hline 3 & 02.11 .2006 & 3711 & 0.06 & 0 \\
\hline 4 & 01.12 .2006 & 3741 & 0.05 & 1.4 \\
\hline 5 & 06.01 .2007 & 3772 & 0.05 & 4.2 \\
\hline
\end{tabular}


Examples of the model reaction for parameter changing

\begin{tabular}{|c|c|c|c|c|c|c|c|c|}
\hline \multirow{2}{*}{ Time step } & \multicolumn{2}{|c|}{ Spring discharge $\left[\mathrm{m}^{3} / \mathrm{d}\right]$} & \multicolumn{3}{|c|}{ Specific yield } & \multicolumn{3}{|c|}{ Hydraulic conductivity [m/s] } \\
\hline & observed & calculated & I layer & matrix & fractures & I layer & matrix & fractures \\
\hline 1 & 18.1 & 19.1 & \multirow{5}{*}{0.23} & \multirow{5}{*}{0.03} & \multirow{5}{*}{0.20} & \multirow{5}{*}{$2.2 \cdot 10^{-6}$} & \multirow{5}{*}{$10^{-9}$} & \multirow{5}{*}{$5 \cdot 10^{-4}$} \\
\hline 2 & 3.5 & 11.7 & & & & & & \\
\hline 3 & 5.2 & 10.1 & & & & & & \\
\hline 4 & 4.3 & 9 & & & & & & \\
\hline 5 & 4.3 & 8.7 & & & & & & \\
\hline \multicolumn{2}{|c|}{ average absolute error $\left[\mathrm{m}^{3} / \mathrm{d}\right]$} & 4.6 & & & & & & \\
\hline 1 & 18.1 & 24.21 & \multirow{5}{*}{0.05} & \multirow{5}{*}{0.03} & \multirow{5}{*}{0.05} & \multirow{5}{*}{$10^{-6}$} & \multirow{5}{*}{$6 \cdot 10^{-10}$} & \multirow{5}{*}{$5 \cdot 10^{-4}$} \\
\hline 2 & 3.5 & 9.29 & & & & & & \\
\hline 3 & 5.2 & 7.16 & & & & & & \\
\hline 4 & 4.3 & 5.05 & & & & & & \\
\hline 5 & 4.3 & 4.47 & & & & & & \\
\hline \multicolumn{2}{|c|}{ average absolute error $\left[\mathrm{m}^{3} / \mathrm{d}\right]$} & 3.0 & & & & & & \\
\hline 1 & 18.1 & 21.8 & \multirow{5}{*}{0.23} & \multirow{5}{*}{0.003} & \multirow{5}{*}{0.05} & \multirow{5}{*}{$10^{-6}$} & \multirow{5}{*}{$6 \cdot 10^{-10}$} & \multirow{5}{*}{$10^{-3}$} \\
\hline 2 & 3.5 & 5.9 & & & & & & \\
\hline 3 & 5.2 & 5.3 & & & & & & \\
\hline 4 & 4.3 & 4.7 & & & & & & \\
\hline 5 & 4.3 & 4.7 & & & & & & \\
\hline \multicolumn{2}{|c|}{ average absolute error $\left[\mathrm{m}^{3} / \mathrm{d}\right]$} & 1.4 & & & & & & \\
\hline
\end{tabular}

fracture zones within the second model layer (WFZ). In calibration progress, there were modified specific yield and hydraulic conductivity of WDR and WFZ (matrix and fractures separately).

The main goal of the model was achieved. The parameters of the uppermost zones (WDR and WFZ) of the system in the Złoty Potok River Basin were assessed which would have been impossible to recognize otherwise.

\section{ZłOTY POTOK RIVER CATCHMENT MODEL - SECOND STAGE}

Experiments made during development of the small-scale model showed that inclusion of the whole river basin in one model may cause problems with so-called "drying cells" and steep hydraulic gradients leading to failure. To avoid these difficulties the FEFLOW code was used (Diersch, 2005) which is based on a finite element method. The advantage of this program is the possibility of mapping the flow according to the Hagen-Poiseuille equation.

The Złoty Potok model area of $4.4 \mathrm{~km}^{2}$ was divided into 93,573 cut pyramid cells using discrete triangular elements. The area of each element is between 40 and $630 \mathrm{~m}^{2}$. Boundary conditions of the second kind $(Q=0)$ were applied to the boundaries of the model and third-kind conditions were used for the first and second model layers. Boundary conditions of the first kind were applied to simulate the adits.

The boundaries of the whole basin model were defined from watersheds, while assuming that there is no flow between basins. This approach is rational, it accepts the hydrodynamic conditions of the system during the hydrological year 2006 and it remains in accordance with a general conceptual model of three water-bearing zones.

The lower limits of water-bearing zones 1 and 2 were accepted according to the established local model. The depth limit of water-bearing zone 3 in the faults was set to $300 \mathrm{~m}$ b.g.l. For zone 2 , from the ground surface, the double porosity model was adopted (Wu et al., 2004) along with fracture flow, which was simulated according to the Hagen-Poiseuille equation.
Fracture distribution in DFN in the river basin area was obtained during our structural mapping of the mine workings; only water-bearing structures were taken into account and other fractures were classified as the rock matrix. The stochastic distribution of water-bearing fractures was then determined based upon a Monte Carlo simulation (Table 2). This approach offers the most reliable results when considering the limited data and the homogeneity of the environment (Berkovitz, 2002). Hypothetical parameter values were generated based upon observations, and then the results were compared with those from field observations (Fig. 7). Divergences between observed and generated fracture patterns originate from the simplification of fracture azimuth (two groups are defined).

Water stickiness at $8^{\circ} \mathrm{C}$ was accepted as characteristic of the area studied (average annual temperature). The fissure hydraulic aperture derived from its transmissivity was set as $0.87 \cdot 10^{-3} \mathrm{~m}$. The permeability of the matrix was assumed to be $6 \cdot 10^{-10} \mathrm{~m} / \mathrm{s}$ as in the local model.

\section{RESULTS}

The final solution obtained during the calibration of the Złoty Potok River catchment model allowed us to meet the many criteria that involve water balance and water table. There was no interchangeable correction of parameters to obtain the hydrogeological solutions directly. The only exception was for the parameters of the individual fractures in the third layer of the model, which became insensitive towards the results generated. The only manifestations of groundwater table in the area investigated are springs. These natural outflow altitudes were used as observation points during calibration. The maximum deviation of the hydraulic head was $3.6 \mathrm{~m}$ and the absolute residual mean was $1.17 \mathrm{~m}$. Satisfactory accordance was also achieved between observed and calibrated elements of water balance. Groundwater runoff, baseflow and discharge from two adits, differs from observation by not more than $3 \%$ (Table 5). 


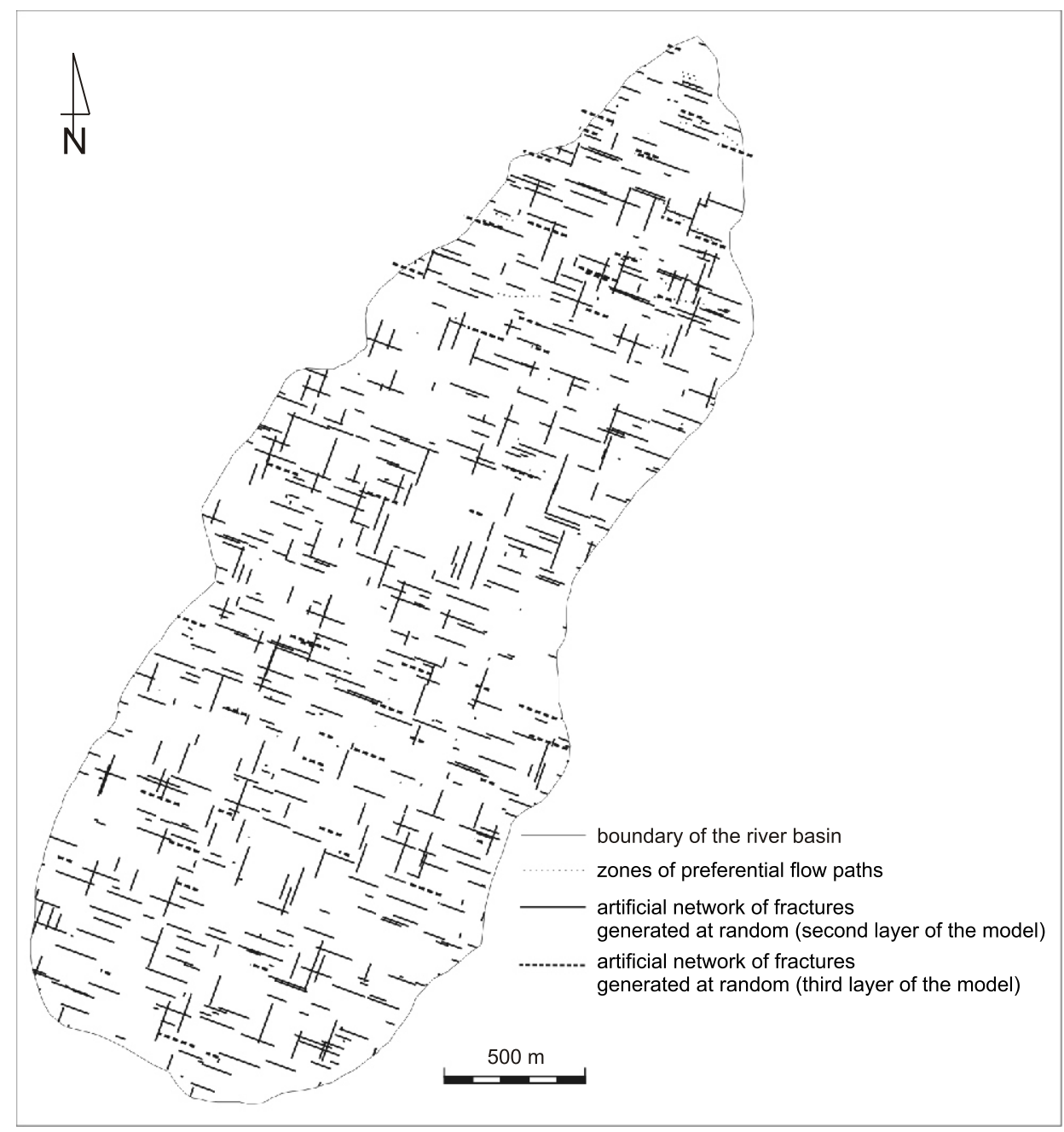

Fig. 7. A comparison of the zones of preferential flow paths observed in the field with those generated by the Monte Carlo method

The outline conceptual model (three zones and the distributions of parameters) was generally confirmed; however, it was reinterpreted, especially in the case of poorly recognized parameters. The calibration showed new characteristic zones not included in the natural model. The first zone is associated with the main axis of the river valley in the deepest zone of the model (25-300 m b.g.I). Influence of the tectonics that determined the origin of the river valley is more significant than expected. It is associated with a zone of hydraulic conductivity $\left(10^{-6} \mathrm{~m} / \mathrm{s}\right)$, raised by four orders of magnitude relative to the rock matrix. This zone is responsible for providing the surface water contact with deep rock formations, and for the basic river flow. The calculated value is important due to the exploration of groundwater resources.
The second zone investigated is connected to the simulation of faults. Initially, the role of faults in the hydrogeological model was simulated using discrete structures with flow according to the Hagen-Poiseuille law. At this stage of the calibration, this was determined more as a zone of raised hydraulic conductivity $\left(1.2 \cdot 10^{-8} \mathrm{~m} / \mathrm{s}\right)$ than a group of discrete structures. In this way there was identified a new domain, which determines the water flow relative to the major faults.

As a result of the model calibration, the value of fissure apertures of strongly fractured zone (from $5 \cdot 10^{-3}$ to $1.1 \cdot 10^{-5} \mathrm{~m}$ ) was substantially reduced. Overestimation of fissure aperture of the second zone may be explained by measurement methodology; values of fissure aperture were estimated in the tunnels where during the drilling stage some fissures were en-

Table 5

Discrepancy between the observed and calculated elements of the water balance

\begin{tabular}{|l|c|c|c|}
\hline & $\begin{array}{c}\text { Observed value } \\
{\left[\mathrm{m}^{3} / \mathrm{d}\right]}\end{array}$ & $\begin{array}{c}\text { Calculated value } \\
{\left[\mathrm{m}^{3} / \mathrm{d}\right]}\end{array}$ & Differences [\%] \\
\hline Groundwater runoff & 2926 & 3009 & 2.7 \\
\hline Base flow & 518.4 & 507.4 & -2.1 \\
\hline Outflow from Czarna Adit & $8-10$ & 8.1 & - \\
\hline Outflow from flooding adit (Czarna Adit) & 37.2 & 36.7 & -1.3 \\
\hline
\end{tabular}


Water balance of the Złoty Potok River Basin model

\begin{tabular}{|l|c|c|}
\hline Elements of balance $\left[\mathrm{m}^{3} / \mathrm{d}\right]$ & Positive & Negative \\
\hline Recharge & 3009 & - \\
\hline River drainage/infiltration & 2736 & 5745 \\
\hline Mine tunnel drainage & - & 45 \\
\hline Total & 5745 & 5790 \\
\hline Discrepancy [\%] & 0.8 & - \\
\hline
\end{tabular}

larged and artificially cleared. Rock matrix permeability remains unchanged $\left(6 \cdot 10^{-10} \mathrm{~m} / \mathrm{s}\right)$.

The water balance of the model consists of two basic components: the recharge of precipitation and water exchange with surface water. As regards the balance, the model was finished with satisfactory accuracy, with discordance below 1\% (Table 6).

In both the Sudetes Mts. and in the Złoty Potok River Basin partial decline of flow in some sections of rivers is characteristic. This phenomenon is associated with the occurrence of karst areas and abandoned tunnels and the model provided its quantitative characterization. Additional river recharge $\left(2736 \mathrm{~m}^{3} / \mathrm{d}\right)$ almost achieves the value of infiltration $\left(3009 \mathrm{~m}^{3} / \mathrm{d}\right.$; Table 6$)$. Hydraulic contact between surface and groundwater is undisturbed, and the river flow is highly sensitive to groundwater table fluctuations. One should expect the periodic decline and even disappearance of flow in some sections of the Złoty Potok River, as is confirmed by field observations.

\section{DISCUSSION}

Groundwater occurs in three environments: the weathered mantle, the profusely fractured crystalline massif, and in deep faults. The numerical model included a detailed investigation in the two latter locations with regard to groundwater flow and the characteristics of the filtration stream. The purpose of the investigation was to gain a perspective of the domains for the location of intakes in the area of the fractured medium.

The intensity of groundwater flow within particular environments directly results from the water balance. The resource of the whole system, which is equal to recharge, amounts to $3009 \mathrm{~m}^{3} / \mathrm{d}$. If we assume that the reliable value of the dynamic resource of the individual environment is its vertical recharge, then we obtain the following values:

- $3009 \mathrm{~m}^{3} / \mathrm{d}$ for zone 1 ;

- $1310 \mathrm{~m}^{3} / \mathrm{d}$ for zone 2 ;

- $502 \mathrm{~m}^{3} / \mathrm{d}$ for zone 3 .

To not exceed the total water recharge in the area of the river basin, its volume may be distributed between the zones in proportion to the value of descending recharge. We obtained the following values:

- weathered mantle $1878 \mathrm{~m}^{3} / \mathrm{d}(62 \%)$;

- fractured massif $818 \mathrm{~m}^{3} / \mathrm{d}(27 \%)$;

- deep faults $313 \mathrm{~m}^{3} / \mathrm{d}(10 \%)$.

It is clear that the weathered mantle holds most of the dynamic resources $(62 \%)$, followed by the fractured bedrock massif $(27 \%)$ and the deep faults $(10 \%)$. Neilson-Welch and Allen (2012) also showed that a large part of flow in headwater streams originates from fractured bedrock. Within zones 2 and 3 , flow takes place through the fracture system as well as through the relatively impermeable matrix. It is worth considering the detail of channel-ways in the fractures. The volumetric flow intensity within the matrix, individual fissures and fault
Participation of water flow environments terms of groundwater renewable resources

\begin{tabular}{|l|c|c|c|}
\hline \multirow{3}{*}{ Layer } & Environment & $\begin{array}{c}\text { Participation in to- } \\
\text { tal discharge [\%] }\end{array}$ & $\begin{array}{c}\text { Groundwater } \\
\text { renewable } \\
\text { resources } \\
{\left[\mathrm{m}^{3} / \mathrm{d}\right]}\end{array}$ \\
\hline \multirow{3}{*}{2} & fractures & 1 & 8 \\
\cline { 2 - 4 } & zones near faults & 90 & 736 \\
\cline { 2 - 4 } & matrix & 9 & 73 \\
\cline { 2 - 4 } 3 & fractures & 1 & 3 \\
\cline { 2 - 4 } & zones near faults & 96 & 300 \\
\hline
\end{tabular}

zones were studied. The results (Table 7 ) show that $90 \%$ of the flow is connected with regions of fractured crystalline rock adjacent to faults in both zones 2 and 3 of the model. The contribution of other isolated fractures is minimal, as suggested by the low inflow to the mine workings from shallow depth bedrock $<20 \mathrm{~m}$ b.g.l. Similar outcomes were provided by Chambel (2012) in southern Italy in a small mountainous basin. The predominant role played by the superficial weathered mantle in the retention of the water resource of the whole system is clear.

In the search for the rock domains of groundwater resources, the frequency distribution of the groundwater flow velocity module was studied. In the Weathered-Fissured Zone in the model, there are three environments that show an increased frequency of occurrence (Fig. 8). The observed flow velocity fluctuates between $10^{-4}-5 \cdot 10^{-4} \mathrm{~m} / \mathrm{d}$ (approximately $1 \%$ of the population; the first domain), $0.1-0.2 \mathrm{~m} / \mathrm{d}$ (approximately $20 \%$ of the population; the second domain), and $2-3 \mathrm{~m} / \mathrm{d}$ (approximately $4 \%$ of the population; the third domain).

The first domain is mostly associated with sub-river bed zone and watershed areas of the Złoty Potok. The second domain has its predominant values of the flow velocity scattered evenly within the area of the river basin. The third domain has its highest values associated with fracture flow.

In zone 3 (FB), one can observe the three clear domains of increased frequency of occurrence of groundwater flow velocity (Fig. 9). It is noticeable that the most dominant values oscillate between $6 \cdot 10^{-6}$ and $4 \cdot 10^{-5} \mathrm{~m} / \mathrm{d}$, which can be easily correlated with the predominant rock matrix. Increased frequency of velocities occurrence also refers to values between $0.87-3.0 \mathrm{~m} / \mathrm{d}$, which relate to the distribution of faults and fractures zones. One can also observe areas in the model with velocity values

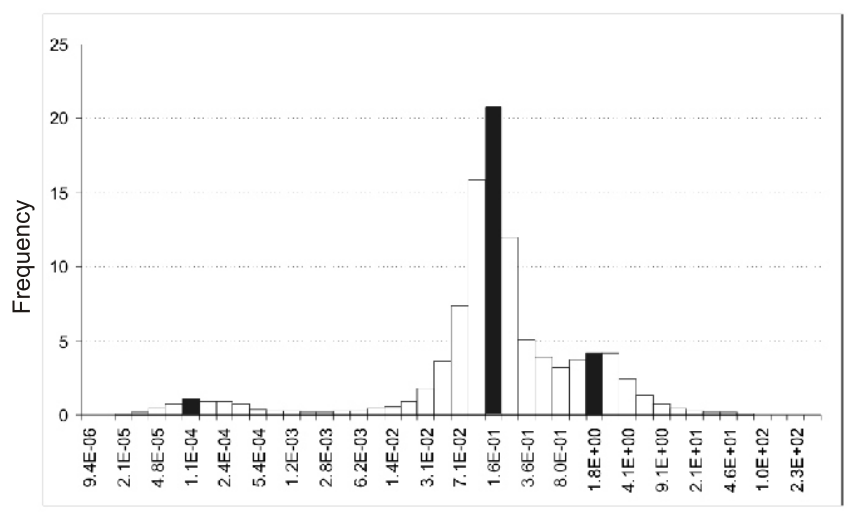

Groundwater flow velocity [m/d]

Fig. 8. Frequency graph of flow velocity in the fractured crystalline massif (zone 2 model layer) 


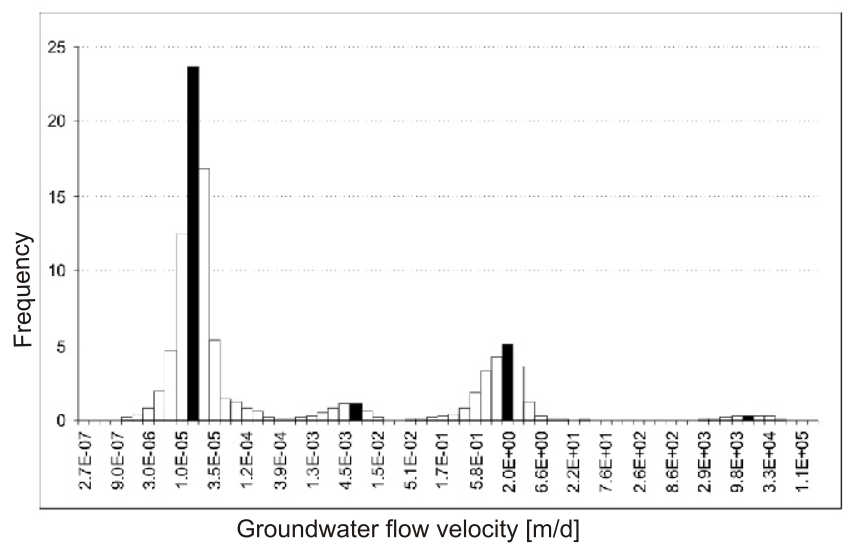

Fig. 9. Frequency graph of flow velocity in the deep faults (zone 3 model layer)

from 3-7 $\cdot 10^{-3} \mathrm{~m} / \mathrm{d}$ associated with sub-stream bed environments. Similar values of flow velocity were obtained by Ayraud et al. (2008) by analysis conducted on a catchment scale in France. The mean percolation value of the entire fractured system (weathered-fissured layer and fractured deep zone) was estimated at $3.5 \cdot 10^{-3} \mathrm{~m} / \mathrm{d}$.

The results of model calibration provided significant new data characterising the hydrogeological system. Separate domains accompanied by faults and the river bed of the Złoty Potok River create potentially beneficial locations for deep groundwater intakes. Analysis of water balance indicates a high instability of surface water resources and suggests utilisation of water-bearing deep zones as a source of groundwater supply. In the conditions described, it was decided to develop a model prognosis of working deep groundwater intakes.

The assessment of potential groundwater exploitation at a particular level in the fracture systems of crystalline rocks requires a specific approach that takes into account the natural limitations of this environment as well as the cost of the investment. The same situation applies to the Złoty Potok River Basin, where consumption exceeds supply leading to a temporary disappearance of river flow. The functionality of the drainage intakes is strictly connected to the total flow regime in the basin. Periods of low rainfall and intensive evapotranspiration contribute to a decrease in the temporary resource, which in consequence forces the necessity to use alternative sources. Considering the natural and anthropogenic disappearance of flow in the Złoty Potok River, the criterion of river flow preservation does not constitute a limiting factor in this study. In this particular case, the measure reflects the efficiency of the drainage system which, from the point of view of groundwater flow, does not require to be analysed. All that needs to be investigated is the location of a stable groundwater resource in the deep zones of the massif.

The previous section described the analysis of the formation of groundwater resources in individual rock domains defined in the river basin. Each one of the environments specifie offers the advantage as groundwater resources. However, some of them appear to be more favourable because of suitable groundwater flow conditions such as high flow velocity or high frequency of oc- currence. Taking this into consideration, the following aspects must be distinguished:

- the faults and their surroundings;

- the sub-river bed regions;

- the matrix regions.

During the investigations the location of 20 hypothetical boreholes in diverse situations were simulated, each approximately $300 \mathrm{~m}$ deep and simulating groundwater extraction from zone 3 with a depression of $30 \mathrm{~m}$. The total efficiency amounted to $1605.5 \mathrm{~m}^{3} / \mathrm{d}$ and reflected a fall in the flow of the Złoty Potok River.

The simulation gave results in the case of the average efficiency of negative boreholes located within the matrix as $11.3 \mathrm{~m}^{3} / \mathrm{d}$ (Fig. 10). A somewhat greater yield of $53.1 \mathrm{~m}^{3} / \mathrm{d}$ was observed for boreholes collecting water from fault zones distant from stream valleys. An insignificantly higher value $\left(71.6 \mathrm{~m}^{3} / \mathrm{d}\right)$ was obtained for the negative boreholes that avoided the faults in the Złoty Potok Valley. The level of possible exploitation of a borehole that delivers water from flow beneath the river valley was much higher $\left(185.1 \mathrm{~m}^{3} / \mathrm{d}\right)$. Studies on the water balance for $100 \mathrm{~m}$ around the borehole showed a lowering of the stream flow by about $25 \%$. The collected water revealed limited contact with surface water.

Detailed flow parameters of fractured rocks have been the subject of many studies, but few of these have analysed less than the entire flow system in one model. Probst (2003) investigated small (less than $100 \mathrm{~km}^{2}$ ) river catchments in eastern Thuringia (Germany). Recharge took place in catchments in a low mountain range, draining metamorphic shales with recharge of ca. $180 \mathrm{~mm} /$ year (i.e., in similar conditions to those in the Złoty Potok River catchment). A black-box model gave outputs similar to those of our research as regards the conductivity of two environments: rock matrix and interconnected fractures, but without any geometrical description. One of the most sophisticated models was made by Ruch and Kupfersberg (2003). The model of the small $\left(0.4 \mathrm{~km}^{2}\right)$ headwater Höhenhansl catchment in Austrian alps allowed simulation of three domains: weathered cover, loose zone and fractured zone in metamorphic schists and gneiss covered by a sandy-loamy weathered layer. Steady-state simulation included the influence of roots and saturated-unsaturated flow. No domains were recognized in the fractured zone and no exploitation was tested.

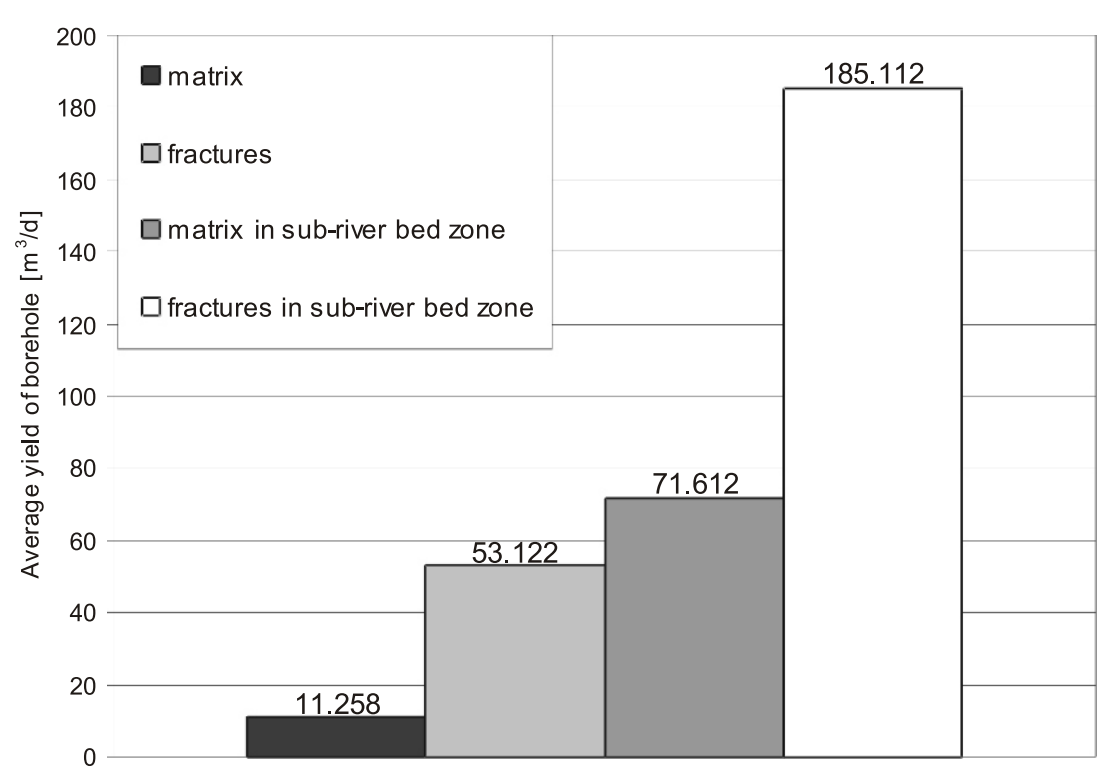

Fig. 10. Potential discharge of deep intakes in the Złoty Potok River Basin depending on flow environment 
A black-box approach was implemented in the case of two small $\left(\sim 1 \mathrm{~km}^{2}\right)$ headwater catchments in the Loch Ard forest in the Central Scottish Highlands (Hrachowitz et al., 2009). The geology of this research area comprised a metamorphic basement covered by siliceous weathering products. A two-reservoir model was developed for input-output analysis of discharge and chemistry, but parameter zonation was not considered.

\section{CONCLUSIONS}

In this paper innovative approach is presented, which allows the obtaining of hydrogeological parameters and their interpretation. Small mountainous catchments are complex research objects. Strongly limited hydrogeological information and co-occurrence of several media require the application of non-standard methods. Where there is of poor information, there is a need to gather a specific range of data: geological setting, fracture measurements (water-bearing and inactive), basal river runoff, river flow disappearance, effective infiltration. This is data without standard information (pumping tests), which allows investigation deeper parts of the hard-rock aquifer.

Parameter identification is a difficult task. The solution proposed is based on two-stage mixed-modelling. First, a local model was created, and then these findings were used to adapt the investigations to the whole river basin model. At the first stage of investigations a small-scale, transient flow conditions, spring catchment model was constructed for an area of $0.25 \mathrm{~km}^{2}$ for an inverse solution of parameters of WDR, using the Visual MODFLOW program. The next stage used the FEFLOW code, enabling a more stochastic approach to be made to the conceptual model, which is comparable to the individual fracture approach.
The groundwater model implemented of whole Złoty Potok River Basin is of mixed-type: a porous media model (with three water-bearing zones) with a discrete fracture model. Analyses of such defined problems are usually performed on different models, at different scales. The solution presented offers high efficiency and allows to analysis of details of groundwater flow specification in different media. Multi-stage model calibration of the Złoty Potok River catchment resulted in defining a flow domain. The domains discovered are groundwater environments different in terms of dynamics, geometry and perspectives for intake locations. A precise prognosis was made which indicated preferred intake locations and the possibility of obtaining relatively high yields.

A similar method of groundwater modelling has been applied by many authors (e.g., Cacas et al., 1990; Svensson, 2001; Wu et al., 2004) but the proposed approach to modelling of small mountainous catchment is tested for the first time.

This should be an initial method of parameter recognition before the stage of borehole drilling. The new approach provides both general resources assessment and individual borehole location.

The similarity of hydrogeological conditions in small hard rock basins has been shown world-wide. The proposed low-cost, new approach can be applied in many mountainous areas, where there is a water deficit.

Acknowledgement. The research for this paper was financed by the Ministry of Science and Higher Education with resources for the years 2006-2007. The authors appreciate the comments and suggestions for improvements by the journal referees.

\section{REFERENCES}

Ayraud V., Aquilina L., Labasque T., Pauwels H., Molenat J., Pierson-Wickmann A.-C., Durand V., Bour O., Tarits C., le Corre P., Fourre E., Merot P., Davy P. (2008) Compartmentalization of physical and chemical properties in hard-rock aquifers deduced from chemical and groundwater age analyses. Applied Geochemistry, 23: 2686-2707.

Balamurugan G., Rajendran D.S., Tirukumaran V. (2010) Impacts of climate, topography and weathering profile on hydrogeology and water resources assessment in semiarid terrain. Using Earth Observation - 1ALI, ASTERDEM and GIS techniques. International Journal of Geomatics and Geosciences, 1 (2): 119-130.

Banks D., Rohr-Torp E., Skarpgagen H. (1994) Groundwater resource in hard rock: experiences from the Hvaler study, southeastern Norway. Applied Hydrogeology, 2: 33-42.

Berkowitz B. (2002) Characterizing flow and transport in fractured geological media: a review. Advances in Water Resources, 25 (8-12): 861-884.

Bocanerga E., Cardoso G. (2003) Groundwater exploitation in fractured rocks in South Africa. In: Proceedings of the IAH International Conference on Groundwater in Fractured Rock, 15-19 September 2003, Prague, Czech Republic: 3-4.

Cacas M.C., Ledoux E., de Marsily G., Tillie B., Barbreau B. Durand A., Feuga B., Peaudecerf P. (1990) Modelling fracture flow with a stochastic discrete fracture network: calibration and validation - the flow model. Water Resources Research, 26 (3): 479-489.

Chambel A. (2012) Groundwater prospecting, drilling and well construction in hard rocks in semi-arid regions: an overview. In: Pro- ceedings of the IAH International Conference on Groundwater in Fractured Rock, 21-24 May 2012, Prague, Czech Republic: 16-17.

Ciężkowski W., Błażej R. (1995) Remarks on water balance of Złoty Jar in Złoty Stok (in Polish with English summary). In: Góry Złote Geologia, Okruszcowanie, Ekologia: 86-88. Materiały Konferencji, Wrocław-Złoty Stok, Poland, 09-10 czerwiec 1995.

Davis S.N., Turk I.J. (1964) Optimum depth of wells in crystalline rocks. Ground Water, 2: 6-11.

Detay M., Poyet P., Emsellem Y., Bernardi A., Aubrac G. (1989) Influence du développement du réservoir capacitif d'altérites et de son état de saturation sur les caractéristiques hydrodynamiques des forages en zone de socle cristallin. Comptes Rendus de l'Académie des Sciences, Paris, 309 (2): 429-436.

Dewandel B., Lachassagne P., Wyns R., Maréchal J.C., Krishnamurthy N.S. (2006) A generalized 3-D geological and hydrogeological conceptual model of granite aquifers controlled by single or multiphase weathering. Journal of Hydrology, $\mathbf{3 3 0}$ (1-2): 260-284

Diersch H.J. (2005) Finite Element Subsurface Flow and Transport Simulation System. User's Manual, FEFLOW Version 5.2. WASY GmbH, Berlin.

Faillace C. (2003) Hydrogeology of hard rocks in some eastern and western African countries. In: Proceedings of the IAH International Conference on Groundwater in Fractured Rock, 15-19 September 2003, Prague, Czech Republic: 19-25.

Gentry W.M., Burbey T.J. (2007) Characterization of ground water flow from spring discharge in a crystalline rock environment. 
Journal of the American Water Resources Association, 40 (5): 1205-1217.

Houston J.F.T., Lewis R.T. (1988) The Victoria Province drought relief project, II. Borehole yield relationships. Ground Water, 26 (4): 418-426.

Howard K.W.F., Hughes M., Charlesworth D.L., Ngobi G. (1992) Hydrogeologic evaluation of fracture permeability in crystalline basement aquifers of Uganda. Applied Hydrogeology, 1: 55-65.

Hrachowitz M., Soulsby C., Tetzlaff D., Dawson J.J.C., Dunn S.M., Malcolm I.A. (2009) Using long-term data sets to understand transit times in contrasting headwater catchments. Journal of Hydrology, 367: 237-248.

Kleczkowski A.S. (1979) Hydrogeologia ziem wokół Polski. Wydawnictwa Geologiczne, Warszawa.

Kowalski S. (1992) The natural factors conditioning occurrence of groundwaters in the Sudety Mts (in Polish with English summary). Acta Universitatis Wratislaviensis, 1324. Prace Geologiczno-Mineralogiczne, 25: 73.

Kryza H., Kryza J. (1986) Odpływ podziemny i zasoby odnawialne Sudetów i ich przedpola jako kryterium regionalizacji hydrogeologicznej. Prace Naukowe Instytutu Geotechniki Politechniki Wrocławskiej, 49, Seria Konferencje, 21: 109-119.

Kryza H., Kryza J. (1988) Hydrogeological conditions of occurrence of natural groundwater outflows in the granite massif of Jakuszyce region on the example of Kamienna river catchment (in Polish with English summary). Acta Universitatis Wratislaviensis, 964. Prace Geologiczno-Mineralogiczne, 11: 99-125.

Kuusela-Lahtinen A., Niemi A., Luukkonen A. (2003) Flow dimension as an indicator of hydraulic behaviour in site characterization of fractured rock. Ground Water, 41 (3): 33-341.

Lachassagne P., Wyns R., Bruel T., Chery L., Coutand T., Desprats J., Strat P. (2001) Exploitation of high-yields in hard-rock aquifers: downscaling methodology combining GIS and multicriteria analysis to delineate field prospecting zones. Ground Water, 39 (4): 568-581.

Lenck P.P. (1977) Données nouvelles sur l’hydrogeology des regions à substratum métamorphique ou éruptif. Enseignements tires de la realisation de 900 forages en Cŏte d'Ivore. Comptes Rendus de l'Académie des Sciences, Paris, 285: 497-500.

Long J.C.S., Gilmur P., Witherspoon P.A. (1985) A model for steady fluid flow in random three-dimensional networks of disc-shaped fractures. Water Resources Research, 21 (8): 1105-1115.

Manga M. (1999) On the timescales characterizing groundwater discharge at springs. Journal of Hydrology, 219: 56-69.

Maréchal J.C., Dewandel B., Subrahmanyam K. (2004) Contribution of hydraulic tests at different scales to characterize fracture network properties in the weathered-fissured layer of a hard rock aquifers. Water Resources Research, 40: 1-17.

McDonald M.G., Harbaugh A.W. (1988) A modular three dimensional finite-difference ground-water flow model. In: Technical of Water Resources Investigations Book, 6, Chap A1. US Geological Survey, Washington, DC.

Neilson-Welch L.A., Allen D.M. (2012) Modelling groundwater capture zones for mountain headwater streams in fractured rock. In: Proceedings of the IAH International Conference on Groundwater in Fractured Rock, 21-24 May 2012, Prague, Czech Republic: 11.

Olichwer T. (2003) Groundwater resources in mountainous areas on the examples of the Śnieżnik Massif and Bystrzyckie Mts (in Polish with English summary). Współczesne Problemy Hydrogeologii, XI, tom 2: 39-42. Wydawnictwo Politechnika Gdańska, Gdańsk.

Olichwer T. (2007a) Groundwater resources of Kłodzko region (in Polish with English summary). Acta Universitatis Wratislaviensis, 3022, Seria Hydrogeologia.

Olichwer T. (2007b) Groundwater renewable resources of Kłodzko region - selected hydrogeologic problems of the Bohemian Massif and of other hard rock terrains in Europe. Acta
Universitatis Wratislaviensis, 3041, Seria Hydrogeologia: 247-258.

Olofsson B. (1994) Flow of groundwater from soil to crystalline rock. Applied Hydrogeology, 2 (3): 71-83.

Paczyński B. (1995) Zasoby, jakość i ochrona zwykłych wód podziemnych. In: Atlas hydrogeologiczny Polski 1:500 000, cz. II. Państwowy Instytut Geologiczny, Warszawa.

Pickens J.F., Grisak G.E., Avis J.D., Belanger D.W., Thury M. (1987) Analysis and interpretation of borehole hydraulic tests in deep boreholes: principles, model development, and applications. Water Resources Research, 23 (7): 1341-1375.

Probst M. (2003) New approaches towards an integrated model-based understanding of groundwater flow in fractured-aquifer catchments and implication for practical problems. In: Proceedings of the IAH International Conference on Groundwater in Fractured Rock, 15-19 September 2003, Prague, Czech Republic: 279-280.

Ruch C., Kupfersberger H. (2003) Modeling the groundwater flow over four years in a small alpine crystalline headwater catchment. In: Proceedings of the IAH International Conference on Groundwater in Fractured Rock, 15-19 September 2003, Prague, Czech Republic: 173-174.

Sawicki L. (1967) Mapa geologiczna Sudetów i bloku przedsudeckiego w skali 1:200 000. Wydawnictwa Geologiczne, Warszawa.

Snow D.T. (1969) Anisotropic permeability of fractured media. Water Resources Research, 5 (6): 173-1289.

Staśko S. (1996) Groundwaters in crystalline rocks in selected areas of Polish part of Sudety Mts (in Polish with English summary). Acta Universitatis Wratislaviensis, 1870. Prace Geologiczno-Mineralogiczne, 53: 1-86.

Staśko S. (2010) On groundwater in crystalline rocks of the Sudetes and their foreland (in Polish with English summary). Biuletyn Państwowego Instytutu Geologicznego, 440: 135-144.

Staśko S., Tarka R. (2002) Recharge and drainage of groundwaters in mountainous areas on the example of Śnieżnik Massif (in Polish with English summary). Acta Universitatis Wratislaviensis, 2528, Seria Hydrogeologia: 1-64.

Svensson U. (2001) A continuum representation of fracture networks, Part II: application to the Aspo Hard Rock Laboratory. Journal of Hydrology, 250: 187-205.

Tarka R. (1997) Groundwaters recharge in mountainous crystalline massifs on the example of Śnieżnik Masyw in the Sudety Mts. (in Polish with English summary). Acta Universitatis Wratislaviensis, Prace Geologiczno-Mineralogiczne, 56, 1-66.

Taylor R., Howard K. (2000) A tectono-geomorphic model of the hydrogeology of deeply weathered crystalline rock: evidence from Uganda. Hydrogeology Journal, 8 (3): 279-294.

Walker D.D., Gylling B., Strom A., Selroos J.O. (2001) Hydrogeological studies for nuclear-waste disposal in Sweden. Hydrogeology Journal, 9 (5): 419-431.

Wojciechowska I. (1995) Budowa geologiczna NE części Ziemi Kłodzkiej jako tło mineralizacji rudnej. In: Góry Złote - Geologia, Okruszcowanie, Ekologia: 7-9. Materiały Konferencji Naukowej Wrocław-Złoty Stok, Poland, 09-10 czerwca 1995.

Wright C.E. (1980) Surface water and groundwater interaction: UNESCO, Studies and Reports in Hydrology, 29: 1-123.

Wright E.P. (1992) The hydrogeology of crystalline basement aquifers in Africa. Geological Society Special Publications, 66: 1-27.

Wyns R., Baltassat J.M., Lachassagne P., Legchenko A., Vairon J., Mathieu F. (2004) Application of SNMR soundings for groundwater reserves mapping in weathered basement rocks (Brittany, France). Bulletin de la Société géologique de France, 175 (1): 21-34.

Wu Y., Liu H., Bodvarsson G. (2004) A triple-continuum approach for modeling flow and transport in fractured rock. Journal of Contaminant Hydrology, 73: 145-179.

Zuber A., Weisse S.M., Osenbruck K., Grabczak J., Ciężkowski W. (1995) Age and recharge area of thermal waters in Ladek Spa (Sudeten, Poland) deduced from environmental isotopes and noble gas data. Journal of Hydrology, 167: 327-349. 